\title{
Economics and Yield Affected by Herbal Extracts in Indian Mustard (Brassica juncea L.)
}

\author{
Manish Meena, Har Vir Singh, R.S. Jat, G.L. Yadav*, M.L. Dotaniya, \\ M.D. Meena, R.L. Choudhary and M.K. Meena
}

ICAR-Directorate of Rapeseed Mustard Research, Bharatpur, Rajasthan, India Mahatma Jyoti Rao Phoole University, Jaipur, India

*Corresponding author

\section{A B S T R A C T}

Keywords

Economics,

Mustard, Irrigation,

Herbal extract,

Yield

Article Info

Accepted:

07 November 2019

Available Online:

10 December 2019
The present investigation was carried out during winter season of 2016-17 at ICAR-Directorate of Rapeseed and Mustard Research, Bharatpur, Rajasthan to evaluate the effect of herbal extracts on growth, economic feasibility, yield and yield attributes of Indian mustard (Brassica juncea L.). The experiment was laid out in randomized block design with four treatments and five replications, viz. herbal extracts, $\mathrm{RDF}+$ one irrigation, $\mathrm{RDF}+\mathrm{KNO}_{3}$ spray and Control. Results revealed that maximum plant leaves (49.6), GMR (₹ 92423), NMR (₹ 61148) and $\mathrm{B}: \mathrm{C}$ ratio (2.96) had with treatment receiving $\mathrm{RDF}+$ one irrigation. The yield and yield attributes; main shoot length $(86.3 \mathrm{~cm})$, seed weight/plant (44.06 g), dry weight/plant $(158.29 \mathrm{~g})$ and yield $(2640 \mathrm{~kg} / \mathrm{ha})$ were highest under the treatment of $\mathrm{RDF}+$ one irrigation as compared to other treatments. This study indicated that application of recommended dose of fertilizers with one irrigation at 65 days after sowing was more beneficial in terms of getting higher yield and economic returns in climatic conditions of Rajasthan.

\section{Introduction}

Indian mustard is a Rabi crop that required relatively cool temperature, a fair supply of soil moisture during its growing season and a dry period during harvest. Indian mustard is predominantly cultivated in Rajasthan, Uttar Pradesh, Haryana, Madhya Pradesh and
Gujarat it is also grown under some nontraditional area of south India including Karnataka, Tamil Nadu and Andhra Pradesh. It is cultivated both under irrigated $(79.2 \%)$ and rain fed $(20.8 \%)$ condition. Being more responsive to fertilizers, gives better return under irrigation condition. Use of organic manure not only helps to sustain crop yield but 
also plays a key role by exhibiting both direct as well as indirect influence on the nutrients availability in soil by improving the physical chemical and biological properties of soil (Singh and Biswas, 2000; Meena et al., 2018).

Among the organic farming practices use of herbal extract or plant extract or botanicals is the emerging concept. Many types of extract from different plant are use for numerous purposes. The utilization of plant extract have been revealed to be eco-friendly and efficient against many plant pathogen. Unlike the chemical farm inputs, extract derived from plants are biodegradable, non-toxic, nonpolluting and non-hazardous to humans, animals and birds.

Herbal extracts from different plants like Terminalia chebula, Termenila belerrica, Terminalia arjuna, Ocimum sanctum, Azdrichta indica, Curcuma longa etc. have been used in various crops as plant growth regulator or plant growth inhibitor. Neem (Azdrichta indica) is considered as the magical tree and hundreds of its active compounds are used in plant protection, neem pest fumigant, neem fertilizer, neem manure, neem compost, neem urea coating agent and neem soil conditioner.

Being a rainfed crop, nutrient management is little or non-existent leading to poor productivity. Site-specific nutrient management, optimum crop geometry, balanced NPK nutrition, management of natural resources, integrated approach to plant-water, nutrient and pest management and extension of rapeseed-mustard cultivation to newer areas under different cropping systems will play a key role in further increasing and stabilizing the productivity and production of rapeseed-mustard to meet out the 39 million tones of vegetable oil requirement in the country by 2050 AD. The present study was undertaken to investigate the effect of herbal extract vis-a-vis chemical fertilizers and irrigation on economics and yield of Indian mustard.

\section{Materials and Methods}

\section{Experimental site and climate characteristics}

The experiment was conducted during 201617 at research farm, ICAR-Directorate of Rapeseed-Mustard Research, Bharatpur located at $77^{\circ} 30^{\prime} \mathrm{E}$ longitude, $27^{\circ} 15^{\prime} \mathrm{N}$ latitude and at an altitude of 178.37 meter above mean sea level. The region falls under Agro climatic Zone III a (semi-arid Eastern plain) with sub-tropical and semi-arid climate.

The climate of this zone is typically semi-arid, characterized with wide range of temperature between summer and winter. High temperature with high wind velocity during summers and low temperature during winters are the characteristic features of climatic condition.

The mean monthly meteorological observations recorded at ICAR-Directorate of Rapeseed-Mustard Research, Bharatpur during the crop growth period. The mean weekly maximum and minimum temperature during the crop growing seasons of mustard fluctuated between 18.3 to $40.9^{\circ} \mathrm{C}$ and 3.5 to $22.1^{\circ} \mathrm{C}$.

The mean daily evaporation from USWB class a pan evaporimeter ranged from 1.0 to $9.7 \mathrm{~mm}$ per day. The average relative humidity fluctuated between 20.4 to 57.8 percent at noon. The bright sunshine hours varied from 5.9 in January to 9.3 in April. Rainfall received during 2016-17 was $55.8 \mathrm{~mm}$.

\section{Soil characteristics}

The soil samples were collected from surface soil $(0-15 \mathrm{~cm})$ and analyzed for soil physicchemical properties with the help of standard 
methods. The experimental site was silty clay loam in texture $(19.2 \%$ sand, $51.3 \%$ silt and $29.4 \%$ clay), $\mathrm{pH}$ (1:2 soil water suspension) 8.3 , bulk density $1.52 \mathrm{~g} \mathrm{~cm} 3$, field capacity (by weight) $12.5 \%$ and permanent wilting point was observed at $2.35 \%$. The nutrient concentration in soil was also measured $0.24 \%, 126.3 \mathrm{~kg} / \mathrm{ha}, 17.23 \mathrm{~kg} / \mathrm{ha}, 149.3 \mathrm{~kg} / \mathrm{ha}$ organic $\mathrm{C}$, available $\mathrm{N}$, available $\mathrm{P}$ and available $\mathrm{K}$, respectively.

\section{Treatment details and preparation of field}

The experiment consisted of four treatments, viz. herbal extracts, RDF+one irrigation, $\mathrm{RDF}+\mathrm{KNO}_{3}$ spray and Control. The herbal extract was prepared using ecotypic vegetations based on traditional knowledge. The variety RH 406 was used as test crop. Mustard was cultivated as per the recommended package and practices of agronomy.

The crop was harvested at 80 per cent silique turned down yellowish brown. The plants from each net plot area $(28 \mathrm{~m} \times 4.5 \mathrm{~m})$ were harvested carefully and seed yield from each plot was recorded.

\section{Observation recorded}

Observations on growth, yield attributing characters, economic parameters and yield were recorded. The data obtained on various observations were tabulated and analyzed factorial randomized block design with three replications by using the techniques of the analysis of variance (ANOVA) as suggested by Panse and Sukhatme (1967) and the treatment was tested by $\mathrm{F}$ test shown their significance where critical difference (CD) at 5\% level of significance was determined for each character to compared the differences among treatment means.

\section{Results and Discussion}

\section{Number of leaf (plant ${ }^{-1}$ )}

Number of leaf (plant ${ }^{-1}$ ) at different stages of plant growth (DAS) as influenced by application of different various treatments (Table 1). Number of leaf (plant ${ }^{-1}$ ) was found significantly higher with treatment $T_{2}$ followed by $\mathrm{T}_{3}$ at different stages of plant growth 45, 60 and 90 DAS.

\section{Main shoot length (cm)}

The data pertaining to main shoot length $(\mathrm{cm})$ as influenced by various treatment is given in Table 2. Among various treatments the significantly higher main shoot length was recorded with $T_{2}$ which was at par with $T_{3}$. Least main shoot length was found in $T_{4}$ (81.24).

\section{Seed weight/plant (g)}

The data on seed weight/plant (g) as influenced by various treatments. Highest seed weight/plant was recorded in treatment $\mathrm{T}_{2}$ which was at par with treatment $\mathrm{T}_{3}$. However least seed weight/plant was recorded in $\mathrm{T}_{4}(34.75 \mathrm{~g})$. Similar findings were also reported by Kingra and Kaur (2012).

\section{Dry weight/plant (g)}

The data on dry weight/plant (g) as influenced by various treatments is given in Table 2 . Treatment $\mathrm{T}_{2}$ recorded the highest dry weight /plant (158.29 g) followed by $\mathrm{T}_{3}, \mathrm{~T}_{1}$ and $\mathrm{T}_{4}$ treatment. Similar findings were also reported by Mandal et al., (2000), Paliwal and Singh (2014).

\section{Seed yield (kg/ha)}

The data pertaining to yield ( $\mathrm{kg} / \mathrm{ha})$ as influenced by various treatment is given in 
Table 3. Treatment of $\mathrm{T}_{2}$ produced highest seed yield $(2640.68 \mathrm{~kg} / \mathrm{ha}$ ) which was found at par with $\mathrm{T}_{3}$ treatment $(2501.7 \mathrm{~kg} / \mathrm{ha})$. The least yield was recorded in $\mathrm{T}_{4}$ (control) treatment i.e. $1469.24 \mathrm{~kg} / \mathrm{ha}$. The significantly highest seed yield of mustard under the treatment of $\mathrm{T}_{2}$ was observed due to significant improvement in yield attributes. These results corroborate the findings of Panda (2000), Bhalerao (2001), Singh et al., (2002), Abraham (2010).

\section{Economic viability of treatments}

The determination of economic indices like cost of cultivation, gross monetary returns (GMR), net monetary returns and $\mathrm{B}$ : $\mathrm{C}$ ratio is the most important parameters to evaluate the effect of the treatments for practical purpose particularly from farmers as well as planner point of view. The farmers mainly interested to earn more profit per unit area, per unit time and investment. The cost of cultivation of Mustard is more that can be judged from common expenditure of Rs 28275/ha. Maximum investment of Rs 31275/ha was needed to grow mustard crop with $T_{2}$, while minimum investment of Rs 26275/ha was incurred under the treatment consisted with $\mathrm{T}_{4}$. The related work was done by Poornima et al., (2010). The GMR is directly related to price rate of produce in the market and total production realized under a particular treatment. The GMR was highest (Rs 92423/ha) under the treatment consisted with $\mathrm{T}_{2}$, while the treatment associated with lower $\mathrm{T}_{4}$ fetched the lowest GMR (Rs 51423/ha). The related work was done by Poornima et al., (2010).

The NMR is the actual profit gained by the farmers as it is determined by deducting the cost of cultivation under a particular treatment from the GMR of the same treatment. It is obvious that NMR increased by increasing various treatment. Consequently, treatment consisted with $\mathrm{T}_{2}$, record the highest NMR (61148.8 Rs/ha) which was closely followed by $\mathrm{T}_{3}$ (56484.5 Rs/ha). While other treatments fetched lesser NMR, the lowest (51423.4 $\mathrm{Rs} / \mathrm{ha}$ ) NMR was found in $\mathrm{T}_{4}$. These findings closely related with Ram et al., (2008) and Biswas et al., (2009). The treatment combination $\mathrm{T}_{2}$ attained the maximum value of GMR and NMR closely followed by $\mathrm{T}_{3}$ due to higher seed yield coupled with lesser cost of cultivation over other combinations. B:C ratio is also termed as profitability. It is a true monetary gain over each rupee of investment under a particular treatment. In other words, it is the ratio of profit over every rupee of investment and it was calculated by dividing the GMR of a particular treatment by the cost of cultivation under the same treatment. The $\mathrm{B}: \mathrm{C}$ ratio was maximum (2.96) with the treatments $\mathrm{T}_{2}$ While the lowest $\mathrm{B}: \mathrm{C}$ ratio (1.96) was calculated under the treatment $\mathrm{T}_{4}$ due to proportionate increase in profit with each rupee of investment. The similar findings were done by Saleem et al., (2001).

Mustard is a one of the important oilseed crop in India. Its production is much influenced by the application of fertilizers and irrigation. Maximum main shoot length, seed weight/plant, dry weight/plant, seed yield, gross monetary returns, net monetary returns and $\mathrm{B}: \mathrm{C}$ ratio was recorded highest with treatment receiving recommended dose of fertilizers N:P:K:S:Zn:B (80:40:40:5:1) along with one irrigation at 65 DAS. On the basis of our finding, it can be concluded that recommended dose of fertilizers with one irrigation is beneficial for getting maximum seed yield and economic returns of Indian mustard in the present ecology. 
Table.1 Effect of different treatments on number of leaf $\left(\right.$ plant $\left.^{-1}\right)$ at different stages of plant growth (DAS)

\begin{tabular}{|c|c|c|c|}
\hline Treatments & \multicolumn{3}{|c|}{ Number of leaf (DAS) } \\
\hline & 45 & 60 & 90 \\
\hline HERBAL & 14.82 & 31.73 & 43.2 \\
\hline RDF+one irrigation $\left(T_{2}\right)$ & 16.33 & 36.76 & 49.6 \\
\hline $\mathrm{RDF}+\mathrm{KNO}_{\mathbf{3}}$ Spray $\quad\left(\mathrm{T}_{\mathbf{3}}\right)$ & 15.53 & 33.83 & 48.83 \\
\hline Control & 13.34 & 30.16 & 42.93 \\
\hline $\mathrm{CD}(\mathbf{P}=\mathbf{0 . 0 5})$ & 1.02 & 4.37 & NS \\
\hline SEm \pm & 0.386 & 1.477 & 1.881 \\
\hline
\end{tabular}

Table.2 Effect of different treatments on yield and yield attributes

\begin{tabular}{|c|c|c|c|c|}
\hline Treatments & $\begin{array}{l}\text { Main shoot } \\
\text { length }(\mathrm{cm})\end{array}$ & $\begin{array}{l}\text { Seed weight / } \\
\text { Plant (gm) }\end{array}$ & $\begin{array}{c}\text { Dry weight / } \\
\text { plant }\end{array}$ & $\begin{array}{l}\text { Seed yield } \\
\text { (kg/ha) }\end{array}$ \\
\hline HERBAL & 82.53 & 37.43 & 144.66 & 2231.02 \\
\hline $\begin{array}{c}\text { RDF+one irrigation } \\
\left(\mathrm{T}_{2}\right)\end{array}$ & 86.33 & 44.06 & 158.29 & 2640.68 \\
\hline $\mathrm{RDF}+\mathrm{KNO}_{3}$ Spray $\left(\mathrm{T}_{3}\right)$ & 84.82 & 41.34 & 157.34 & 2501.7 \\
\hline Control $\quad\left(\mathbf{T}_{4}\right)$ & 81.24 & 34.75 & 122.21 & 1469.24 \\
\hline $\mathrm{CD}(\mathrm{P}=\mathbf{0 . 0 5})$ & 7.84 & 14.08 & 53.97 & 521.58 \\
\hline SEm \pm & 2.631 & 4.57 & 16.747 & 171.787 \\
\hline
\end{tabular}

Table. 3 Economics of the treatment under various treatments

\begin{tabular}{|c|c|c|c|c|}
\hline Treatments & Cost of Cultivation & GMR & NMR & B:C Ratio \\
\hline HERBAL & 28275 & 78085.7 & 49810.7 & 2.76 \\
\hline $\begin{array}{c}\text { RDF +one irrigation } \\
\left(\mathbf{T}_{2}\right)\end{array}$ & 31275 & 92423.8 & 61148.8 & 2.96 \\
\hline $\mathrm{RDF}+\mathrm{KNO}_{3}$ Spray $\left(\mathrm{T}_{3}\right)$ & 31075 & 87559.5 & 56484.5 & 2.82 \\
\hline Control & 26275 & 51423.4 & 25148.4 & 1.96 \\
\hline
\end{tabular}

\section{References}

Abraham T, Sharma UC, Thenua OVS and Shivakumar BG. 2010. Effect of levels of irrigation and fertility on yield and economics of chickpea (Cicer arietinum) and Indian mustard (Brassica juncea) under sole and intercropping systems. Ind J Agril Sci,
80(5): 372-376.

Biswas, M., Najrul Islam., Islam, $\mathrm{S}$ and Masood Ahmed. 2009. Seedling raising Method for production of transplanted maize. International Journal of Sustainable Crop production. 4 (2): 6-13.

Kingra PK and Kaur P. 2012. Yield and water use efficiency of oilseed brassica as 
influenced by irrigation levels under normal and late sown conditions in Punjab. J Agril Phy, 12(1): 44-53.

Mandal KG, Kuntal $\mathrm{H}$ M and Misra AK. 2000. Interdependence of irrigation and nutrient management effects on growth and nutrient use efficiencies in mustard. National Seminar on Oilseed and Oils Research and Development Needs in the Millennium, DOR, Hyderabad. 30

Meena MD, Narjary B, Sheoran P, Jat HS, Joshi PK, Anil R Chinchmalatpure, Yadav Gajender, Yadav RK, and Meena MK. 2018. Effect of Rice straw compost and mineral fertilizers on yield and nutrient uptake by Indian mustard in saline soil. Journal of Oilseed Brassica. 9 (1): 195-200.

Paliwal A and Singh JP. 2014. Response of mustard [Brassica jucea (L.) Czernj. \& Cosson] to potassium with other nutrients, field and quality. The Bioscan, 9 (2): 649-652.

Panse V G, and Sukhatme P V. 1967. Statistical methods for Agricultural Workers, ICAR, Publication New Delhi.

Poornima, D. S., Shankaralingappa, B. C., Kalyana Murthy, K. N and Savitha, H.
R. 2010. Economics of transplanted pigeonpea in sole cropping and finger millet based intercropping system. International Journal of Agricultural Sciences. 6 (2): 501-503.

Ram, Pyare; Prasad, Kedar; Dixit, Vivek; Khan, Naushad and Sonker, T. C. (2008). Effect of row spacing and sulphur on growth, yield attributes, yield and economics of mustard [Brassica juncea (L.) Czern \& Coss]. Plant Archives, 8(2): 633-635.

Saleem, Muhammad, Cheema, Mumtaz Akhtar and Malik, M. Asghar (2001). Agro economic assessment of canola planted under different levels of nitrogen and row Spacing. Int. J. Agri. Biol., 3(1): 27-30.

Singh DV and Biswas K. 2000. N-S interaction as affecting yield and mustard uptake in mustard-moong cropping sequence under various nutrient combinations. Crop Res, 19(3): 403-408.

Singh F, Sinsinwar B S, Kumar PR, and Premi OP. 2002. Effect of different levels of irrigation and nitrogen on yield and oil content of Indian mustard (Brassica juncea). J Oil Res. 19 (1): 62-63.

\section{How to cite this article:}

Manish Meena, Har Vir Singh, R.S. Jat, G.L. Yadav, M.L. Dotaniya, M.D. Meena, R.L. Choudhary and Meena, M.K. 2019. Economics and Yield Affected by Herbal Extracts in Indian Mustard (Brassica juncea L.). Int.J.Curr.Microbiol.App.Sci. 8(12): 628-633. doi: https://doi.org/10.20546/ijcmas.2019.812.082 